УДК 338.2:343.37

JEL Classification: K34, H26, E6

(C) Мазуренко О.В., Тютюник І.В., Білоус Ю.Г., 2021

Сумський державний університет, Суми

\title{
СИСТЕМАТИЗАЦІЯ ФАКТОРІВ ФОРМУВАННЯ ПОДАТКОВОЇ КОНКУРЕНТОСПРОМОЖНОСТІ КРАЇНИ
}

\begin{abstract}
Проведено аналіз факторів формування податкової конкурентоспроможсності краӥни. Здійснено порівняльний аналіз рівня податкового навантаження окремих краӥн світу. Обгрунтовано роль окремих складових державної податкової політики (кількість податкових платежів, рівень податкового навантаження, ефективність діяльності державних податкових органів у напрямку фінансового моніторингу та контролю за повнотою нарахування та сплати податкових платежів, стабільність податкового законодавства) у зниженні податкової конкурентоспроможності країни. Проаналізовано динаміку зміни місия позиціонування України в основних міжнародних рейтингах. За результатами аналізу зроблено висновок про необхідність реформування існуючої системи оподаткування в Украӥні з точки зору приведення ії у відповідність міжнародним стандартам, оптимізації податкового законодавства та функиіонування на принципах сталості та узгодженості.

Ключові слова: податкова конкурентоспроможність, податкова система, інвестиційна привабливість, рівень податкового навантаження, ставка податку
\end{abstract}

Постановка проблеми. Глобалізація фінансового та інвестиційного ринків, лібералізація торговельних відносин, значний дефіцит ресурсів у більшості секторів економіки актуалізували потребу пошуку додаткових джерел залучення капіталу та підвищення інвестиційної привабливості країни. Одним із показників, що визначає привабливість країни для міжнародних інвесторів, зумовлює сприятливість iii бізнес-середовища, $\epsilon$ рівень податкової конкурентоспроможності. Будучи інтегральним показником, що узагальнює в собі різні складові державної податкової політики та визначає ефективність їх функціонування, податкова конкурентоспроможність $\epsilon$ важливим індикатором, що свідчить на користь започаткування підприємницької діяльності на території конкретної країни. Усвідомлюючи всю важливість даного показника при здійсненні міжнародної діяльності, уряди країн спрямовують свої зусилля на підвищення своїх конкурентних позицій в напрямку реалізації своєї податкової політики. Це зумовило активізацію зусиль науковців та практиків в напрямку ідентифікації факторів, що здійснюють найбільший вплив на рівень податкової конкурентоспроможності країни та визначення, на цій основі, найбільш ефективного інструментарію його зростання.

Аналіз останніх досліджень і публікацій. Дослідженням питань забезпечення високого рівня податкової конкурентоспроможності країни та обгрунтуванням шляхів ऑii підвищення займалася значна кількість науковців. Так, Я. Самусевич у [9] займалася дослідженням економічного змісту поняття податкової конкурентоспроможності країни як системи економічних відносин, що виникають як між окремими країнами, так i їх об’єднаннями, в результаті залучення внутрішніх і зовнішніх фінансових ресурсів - об'єктів оподаткування, в основу яких складають диференціація ставок податків і зборів, маніпулювання 3 умовами та об'єктами оподаткування.

Рівень конкурентоспроможності податкової системи України на основі порівняльного аналізу значень міжнародних рейтингів визначено I. Р. Безпалько [7]. За результатами аналізу автором визначено основні напрями реформування податкової системи України як передумови підвищення іiі конкурентоспроможності.

Причинно-наслідковий зв'язок рівня податкової конкурентоспроможності країни 3 рівнем матеріального добробуту іï населення досліджений у [8] О. В. Нєізвестна, О. В. Овчаренко, І. В. Гребенюк. На основі аналізу рівня оподаткування доходів фізичних осіб i співвідношення рівнів мінімальної заробітної плати до прожиткового мінімуму авторами обгрунтовано доцільність трансформації існуючої системи оподаткування в Україні з точки зору іiі приведення у відповідність 3 міжнародними стандартами.

Незважаючи на наявність значної кількості публікацій, присвячених дослідженню даної проблематики, більшість із них досліджує вплив лише окремих факторів на рівень податкової конкурентоспроможності країни не враховуючи при цьому всю їх множинність і різноманітність. Водночас, саме врахування всього спектра факторів підвищення податкової конкурентоспроможності країни дозволяє оптимізувати систему оподаткування в країні та поліпшити тим iii інвестиційний клімат.

Формулювання цілей статті (постановка завдання). Мета статті - аналіз і систематизація 
факторів формування податкової конкурентоспроможності країни як передумови підвищення iii інвестиційної привабливості та поліпшення бізнес-клімату.

Виклад основного матеріалу дослідження. Одним із інструментів, що дозволяє оцінити ступінь актуальності досліджуваної проблематики та рівень іiі дослідженості, $€$ інструментарій Google Trends. На основі трендового аналізу динаміки зміни кількості пошукових запитів користувачів пошукової системи Google (табл. 1.1) можна зробити висновок про низький рівень дослідженості даних питань. Так, протягом останніх 12 років кількість запитів користувачів знаходиться на критично низькому рівні.

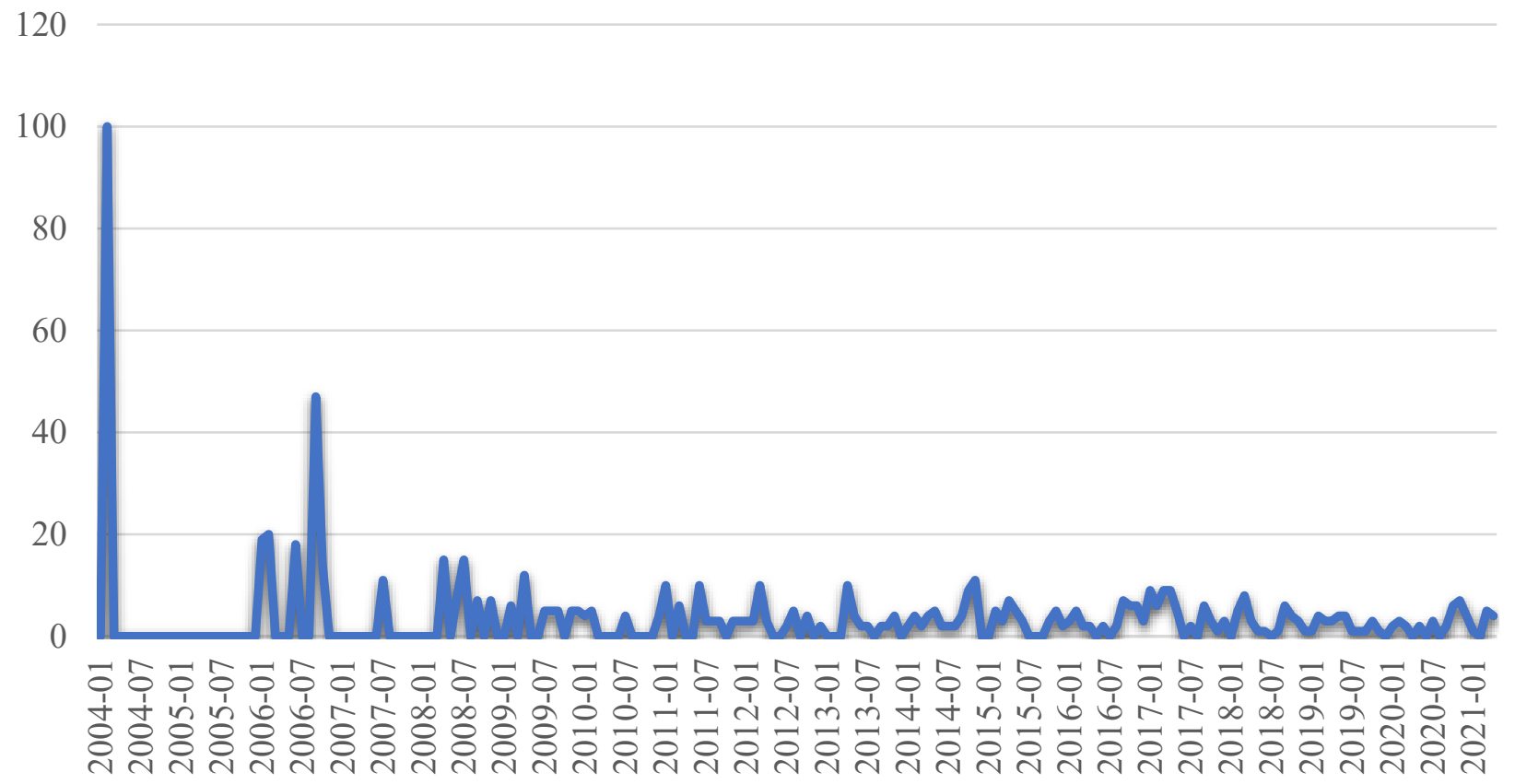

Рис. 1. Динаміка зміни частоти пошукових записів користувачів Google 3 питань податкової конкурентоспроможності

*Джерело: побудовано авторами за допомогою інструментарію Google Trends

Водночас, протягом останніх років питання оптимізації податкового навантаження, зменшення витрат часу та коштів на оформлення податкової звітності розглядаються урядами більшості країн світу як один із найбільш ефективних інструментів поліпшення показників функціонування бізнесу, зростання обсягів податкових надходжень до бюджету, зниження обсягів ухилень від сплати податкових платежів.

Рівень податкової конкурентоспроможності країни залежить від низки факторів, основним 3 яких $є$ ефективність їі податкової системи, в основі яких урахування таких складових: кількість податкових платежів, рівень податкового навантаження, ефективність діяльності державних податкових органів у напрямку фінансового моніторингу та контролю за повнотою нарахування та сплати податкових платежів, стабільність податкового законодавства. Дані фактори здійснюють безпосередній вплив на привабливість країни 3 боку іноземних інвесторів щодо фінансування програм і реєстрації бізнесу на даній території. Крім того, низький рівень конкуренто- спроможності країни сприяє виведенню коштів на території інших юрисдикцій 3 більш сприятливими умовами оподаткування за рахунок реєстрації бізнесу за кордоном.

Сучасна система оподаткування в Україні, незважаючи на іiі грунтовне реформування протягом останніх років, характеризується низкою недоліків. Так, зокрема, один із факторів, що здійснює негативний вплив на рівень податкової конкурентоспроможності України, надмірний податкових тиск на економічних суб'єктів.

Одним із узагальнюючих показників, що відображає ступінь сприятливості умов для ведення бізнесу, $є$ міжнародний Індекс легкості ведення бізнесу, значення якого щорічно розраховуються представниками Світового банку. Даний індекс розраховується для 190 країн світу в межах 12 сфер ділової активності, зокрема: започаткування бізнесу, отримання дозволів на будівництво, отримання електроенергії, реєстрація прав власності, отримання кредиту, захист прав інвесторів, сплата податків, міжнародна торгівля, примусове 
виконання контрактів i врегулювання неплатоспроможності. Крім того даний індекс оцінює норми щодо найму працівників та укладення контрактів з урядом.

Міжнародною організацією PricewaterhouseCoopers i представниками Світового банку щорічно проводиться оцінка ефективності функціонування податкових систем більшості країн світу. У виданні «Рaying Taxes 2019: The Global Picture» однією із тенденцій функціонування сучасних податкових систем визначено активне запровадженнями урядами заходів, спрямованих на їх реформування та оптимізацію податкового законодавства [5].
Реформування податкової системи в Україні, що супроводжувалося скороченням кількості податкових платежів і оптимізацією податкового навантаження, призвело до поліпшення позицій України в даному рейтингу. Так, якщо у 2012 році Україна займала 152 позицію серед 190 можливих, то прийняття у 2014 році нового Податкового кодексу сприяло суттєвому поліпшенню i позицій (у 2014 році 112 місце серед 190) i вже за результатами 2020 року Україна займає 64 місце серед досліджуваних країн (рисунок 2).

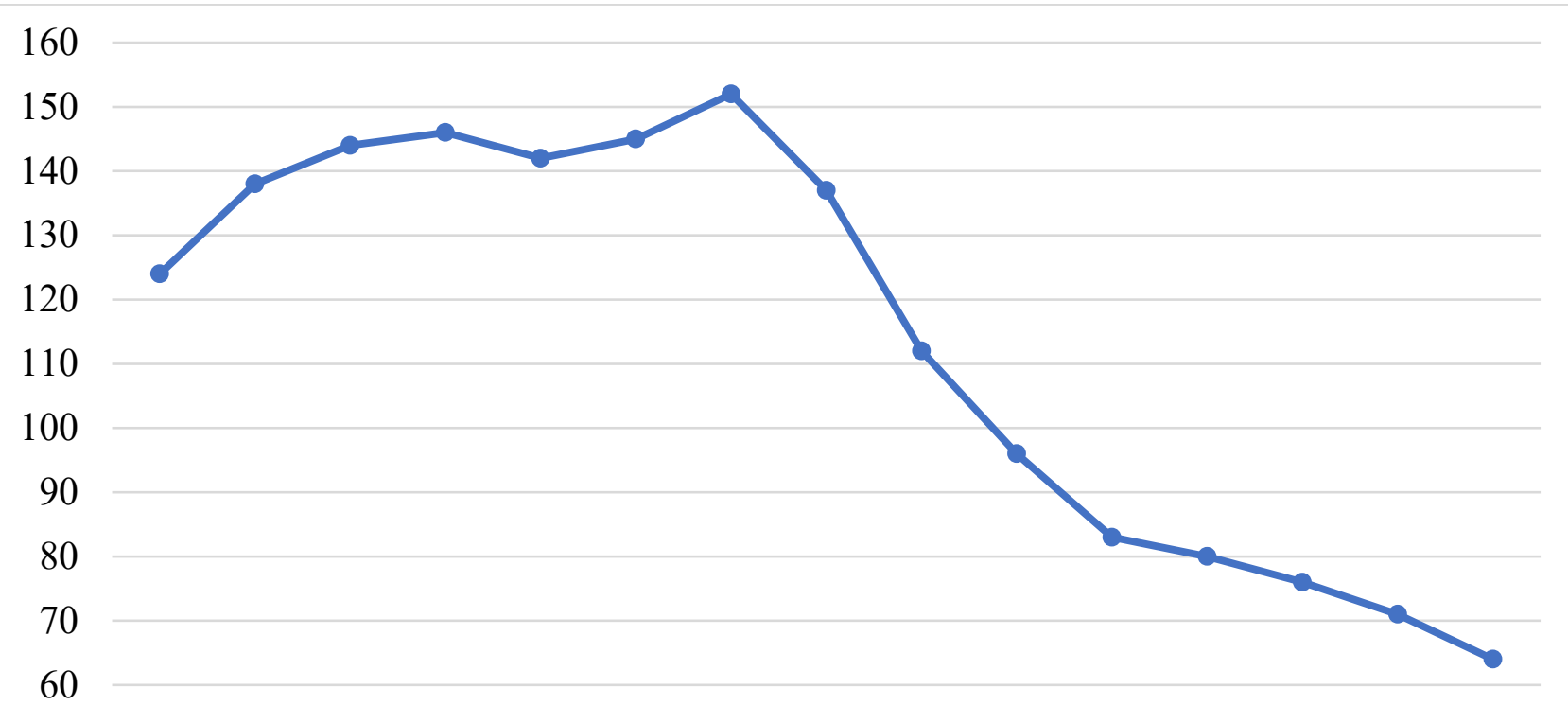

200620072008200920102011201220132014201520162017201820192020

Рис. 2. Динаміка зміни позицій України за індексом легкості ведення бізнесу

*Джерело: побудовано авторами на основі [1].

Аналіз Індексу легкості ведення бізнесу в розрізі окремих його складових (таблиця 1) свідчить про наявність суттєвих відмінностей у побудові державної податкової політики різних країн світу. Наприклад, в Україні за достатньо невеликої кількості податкових платежів тривалість підготовки податкової звітності та сплати податків $є$ однією із найвищих серед аналізованих країн. Якщо в Румунії тривалість підготовки податкової звітності та сплати податків для 14 платежів становить 163 години, то в Україні при наявності лише 5 платежів підготовка звітності займає 328 годин на рік.

Досить трудомісткими та вартісними $є$ реалізація операцій експорту та імпорту. Якщо для решти аналізованих країн відсутня вартість оформлення документів при експорті/ імпорті, то в Україні вона становить 192/162 доларів США, а вартість проходження контролю при експорті/ імпорті - 75/100 доларів США відповідно, за іï відсутності в решті країн.

Високий і загальний рівень податкового навантаження в Україні, який за результатами 2020 року становив 45,2\%. А порівняльний аналіз ставок основних бюджетоформуючих податків у розрізі окремих країн світу засвідчив середній їх рівень. Базові ставки податку на прибуток підприємств, ПДВ і ПДФО знаходяться на рівні, а інколи $€$ набагато меншим за навантаження більшості країн світу. Так, якщо в Україні базова ставка податку на прибуток становить $18 \%$, то в Німеччині вона становить $29,65 \%$, Японії $29,74 \%$, Італії - 27,9\%. Навантаження за ПДВ в Україні знаходиться на середньому рівні (20\%), що теж здійснює вагомий вплив на рівень податкової конкурентоспроможності України порівняно з рештою країн світу. Водночас, низька якість інституційної складової політики нарахування та сплати податків актуалізує 
потребує перегляду ефективності процедур нарахування та сплати податків і контролю на повнотою їх обліку.

\section{Порівняльний аналіз складових Індексу легкості ведення бізнесу у 2020 році}

Таблиия 1

\begin{tabular}{|l|c|c|c|c|c|}
\hline \multicolumn{1}{|c|}{ Показник } & Польща & Румунія & Хорватія & Угорщина & Україна \\
\hline Кількість податкових платежів & 7 & 14 & 12 & 11 & 5 \\
\hline $\begin{array}{l}\text { Час на підготовку податкової звітності та } \\
\text { сплату податків, годин/рік }\end{array}$ & 334 & 163 & 206 & 277 & 328 \\
\hline Рівень податкового навантаження & 40,8 & 20 & 20,5 & 37.9 & 45,2 \\
\hline $\begin{array}{l}\text { Час на прикордонний та митний контроль } \\
\text { при експорті/імпорті, годин/рік }\end{array}$ & $0 / 0$ & $1 / 1$ & $0 / 0$ & $0 / 0$ & $6 / 32$ \\
\hline $\begin{array}{l}\text { Час на оформлення документів при } \\
\text { експорті/імпорті, годин/рік }\end{array}$ & $1 / 1$ & $0 / 0$ & $1 / 1$ & $1 / 1$ & $66 / 48$ \\
\hline $\begin{array}{l}\text { Вартість оформлення документів при } \\
\text { експорті/ імпорті, доларів США }\end{array}$ & $0 / 0$ & $0 / 0$ & $0 / 0$ & $0 / 0$ & $192 / 162$ \\
\hline $\begin{array}{l}\text { Вартість проходження контролю при } \\
\text { експорті/ імпорті, доларів США }\end{array}$ & $0 / 0$ & $0 / 0$ & $0 / 0$ & $0 / 0$ & $75 / 100$ \\
\hline
\end{tabular}

*Джерело: побудовано автором на основі [1]

Вищезазначені особливості існування податкової системи в Україні $\epsilon$ суттєвим інгібітором формування сприятливого бізнессередовища в країні. Інвестори, як правило, зацікавлені в інвестуванні коштів на території $з$ більш привабливими умовами оподаткування, здатними забезпечити мінімізацію витрат часу та ресурсів. Бізнес-структури прагнуть здійснювати діяльність на територіях 3 нижчим рівнем податкового навантаження. Досить часто це спонукає представників бізнесу до реєстрації своїх фірм на територіях інших країн 3 подальшим здійсненням діяльності на території України, але сплатою податків за кордоном.

\section{Порівняння ставок податків в окремих країнах світу}

\begin{tabular}{|l|l|c|c|c|}
\hline \multicolumn{1}{|c|}{ Кo } & \multicolumn{1}{|c|}{$\begin{array}{c}\text { Праїна } \\
\text { Податок на } \\
\text { прибуток }\end{array}$} & ПДВ & ПДФО \\
\hline 1. & Австралія & $25 \%$ & 20 & $0 / 55$ \\
\hline 2. & Бельгія & 25 & 21 & $25 / 50$ \\
\hline 3. & Естонія & 0 & 20 & 20 \\
\hline 4. & Італія & 27,9 & 22 & $23 / 47$ \\
\hline 5. & Канада & 26,5 & 5 & $19 / 44.5$ \\
\hline 6. & Китай & 25 & 13 & $0 / 45$ \\
\hline 7. & Латвія & 0 & 21 & $20 / 31,4$ \\
\hline 8. & Литва & 29,65 & 21 & $31,2 / 42,77$ \\
\hline 9. & Німеччина & 19 & 19 & $14 / 47,475$ \\
\hline 10. & Польща & 21 & 23 & $17 / 32$ \\
\hline 11. & Португалія & 21 & 23 & $14,5 / 48$ \\
\hline 12. & Словацька республіка & 19 & 22 & $19 / 25$ \\
\hline 13. & Словенія & 21 & 11,725 & $16 / 50$ \\
\hline 14. & США & 18 & 20 & $10 / 51,6$ \\
\hline 15. & Україна & 26,5 & 20 & 18 \\
\hline 16. & Франція & 19 & 21 & $20.1 / 45.7$ \\
\hline 17. & Чеська республіка & 29.74 & 10 & $15.105 / 55.949$ \\
\hline 18. & Японія & & & \\
\hline
\end{tabular}

*Джерело: побудовано автором на основі [1] 
На думку експертів, однією $з$ особливостей сучасної системи оподаткування в Україні є іiі орієнтація на виконання, переважно, фіскальної функції податків, що полягає в розумінні податків як основного джерела наповнення бюджету, а не інструменту виконання державою покладених на неї зобов'язань. Тож рівень податкового навантаження в країні залежить здебільшого від потреб держави у фінансових ресурсах, а не від обсягу благ і послуг, що мають бути надані населенню.

За цих умов запровадження більш сприятливих (пільгових) умов оподаткування здійснюється винятково 3 метою впливу на поведінку економічних суб'єктів - платників податку і досить часто виступає інструментом маніпулювання $з$ боку представників державної влади.

Окремі якісні аспекти функціонування податкової складової державної економічної політики враховуються значною кількістю міжнародних індексів. Наприклад, в основі розрахунку Індексу економічної свободи - врахування 12 факторів, у тому числі податковий тягар і фіскальне здоров'я у країні. Даний Індекс розраховується Wall Street Journal i Heritage Foundation щорічно, починаючи з 1995 року для 186 країн світу. За даним Індексом усі країни поділяються на 5 груп: країни 3 вільною економікою (значення Індексу від 80,0 до 100,0); 3 переважно вільною економікою $(70,0-79,9) ; 3$ помірно вільною економікою $(60,0-69,9) ; 3$ переважно невільною економікою $(50,0-59,9) ; 3$ репресивною економікою $(0-49,9)$ [4].

За даними 2019 року, Україна належить до країн із переважно невільною економікою $(52,3)$. Аналіз динаміки зміни позицій України за даним індексом наведений на рисунку 3 свідчить про незначне поліпшення іiі позицій за період 20102019 рр. Якщо у 2010 році індекс економічної свободи в Україні складав 46,4, то за результатами 2019 року його значення підвищилося до 52,3. Аналогічними тенденціями характеризуються і значення Індексу податкової свободи, рівень якого набагато перевищує середньосвітове значення $(77,8)$.

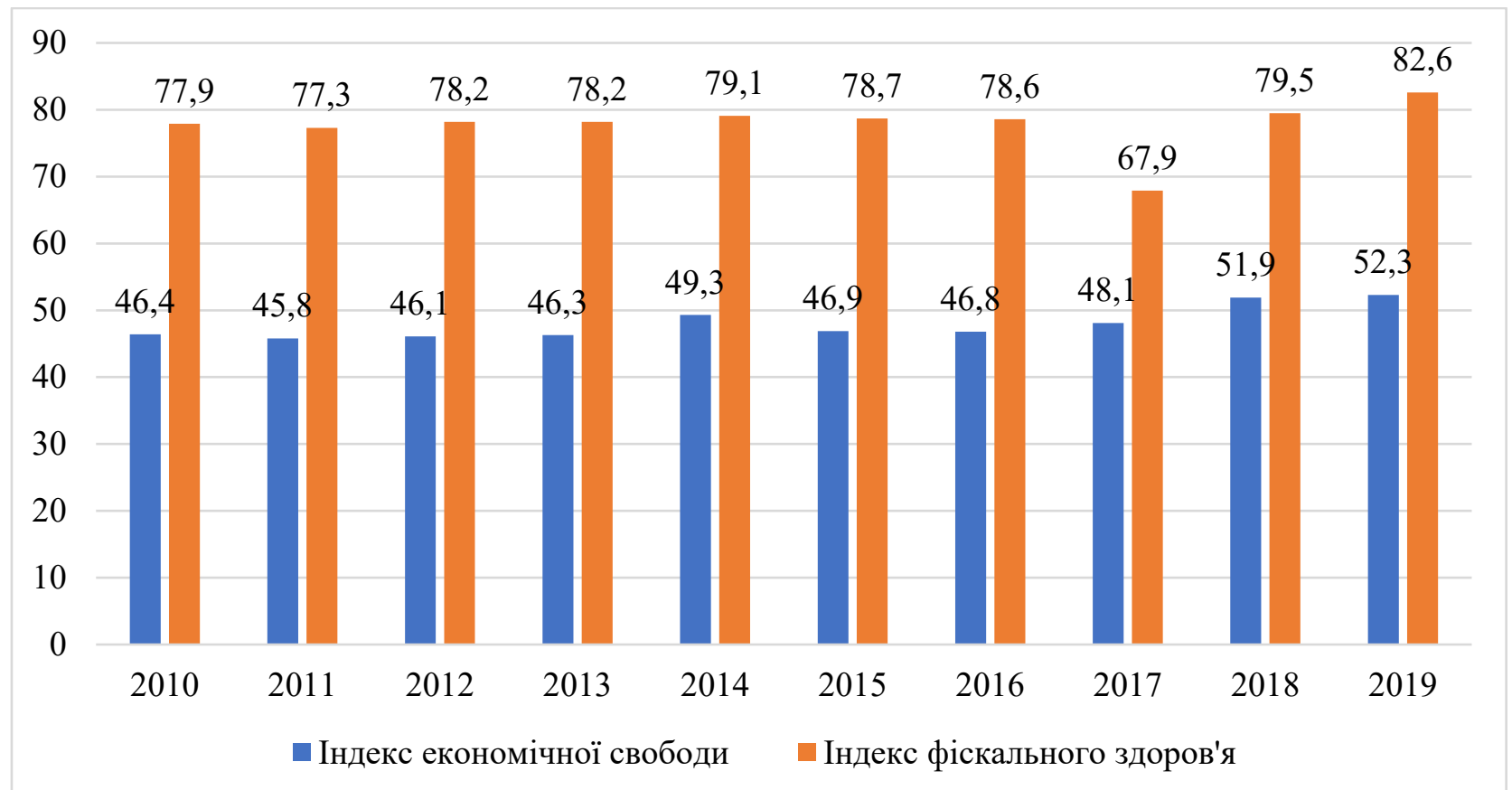

Рис. 3. Динаміка зміни Індексів економічної та податкової свободи в Україні

*Джерело: побудовано автором на основі [4].

Не менш важливим фактором підвищення рівня податкової конкурентоспроможності країни $\epsilon$ стабільність податкового законодавства, що визначає умови ведення бізнесу в країні. Поряд із низкою позитивних моментів, що характеризують податкову систему України останніх років, саме мінливість податкового законодавства виступає одним із головних інгібіторів на шляху економічного зростання в країні та зростання іiі інвестиційного потенціалу. Зміни, що вносяться до нормативних актів i регулюють питання оподаткування, досить часто лише поглиблюють існуючі невідповідності в законодавстві. Як правило, дані зміни носять неузгоджений та несистемних характер, спричиняють невідповідність норм різних нормативних актів між собою та в цілому не відповідають принципам сталості та узгодженості. 
Існуючі недоліки в податковій системі України призводять до низьких іiі позицій у міжнародних рейтингах, окремі значення яких наведені в таблиці 3.

Так, протягом аналізованого періоду відбулося поступове зниження позицій Україні за значенням Індексу глобальної конкурентоспроможності 85-е місце у 2019 році порівняно із 76 у 2014 році. Практично без змін залишається позиціонування України за Індексом людського розвитку Глобальним індексом привабливості іноземних прямих інвестицій.

Таблиия 3

Позиціонування України в міжнародних індексах

\begin{tabular}{|c|c|c|c|}
\hline Рік & $\begin{array}{c}\text { Індекс Глобальної } \\
\text { конкурентоспроможності } \\
\text { (140 країн) }\end{array}$ & $\begin{array}{c}\text { Глобальний індекс } \\
\text { привабливості іноземних прямих } \\
\text { інвестицій } \\
\mathbf{( 1 0 9} \text { крайн) }\end{array}$ & $\begin{array}{c}\text { Індекс } \\
\text { людського } \\
\text { розвитку } \\
\text { (189 країн) }\end{array}$ \\
\hline 2013 & 84 & 68 & 81 \\
\hline 2014 & 76 & 61 & 81 \\
\hline 2015 & 79 & 58 & 84 \\
\hline 2016 & 85 & 59 & 83 \\
\hline 2017 & 83 & 59 & 84 \\
\hline 2018 & 83 & 59 & 74 \\
\hline 2019 & 85 & 58 & 74 \\
\hline
\end{tabular}

*Джерело: узагальнено авторами за даними [2, 3, 6].

Висновки. Результати проведеного аналізу засвідчують актуальність проблем удосконалення існуючої податкової системи України 3 точки зору приведення іiі у відповідність міжнародним стандартам, оптимізації податкового навантаження, зменшення тривалості процедур нарахування та сплати податків, оформлення документації. Реалізація даних заходів вимагає імплементації низки змін до нормативноправових актів, приведення їх у відповідність одне одному, удосконалення інституційної складової державної податкової політики з точки зору підвищення ефективності роботи податкової органів, процедур фінансового моніторингу та контролю за повнотою нарахування та сплати податків

\section{Список літератури}

1. Doing Business - 2017: Economy Rankings. World Bank Group.. URL: http://www.doingbusiness.org/

2. Global Foreign Direct Investments Country Attractiveness Index. URL: http://www.fdiattractiveness.com/ranking-history/

3. Human Development Reports. URL: http://hdr.undp.org/en/content/human-development-indexhdi

4. Index Economic Freedom. URL: https://www.heritage.org/index/

5. PricewaterhouseCoopers.

URL: https://www.doingbusiness.org/en/reports/thematicreports/paying-taxes-2019

6. The Global Competitiveness Report. URL: https://www.heritage.org/index/
7. Безпалько I. Р. Аналіз конкурентоспроможності податкової системи України в сучасних глобалізаційних умовах. Ефективна економіка. 2015. URL:

http://www.economy.nayka.com.ua/pdf/10_2015/26.pdf

8. Нєізвєстна О. В., Овчаренко О. В., Гребенюк I. В. Податкова конкурентоспроможність як індикатор рівня добробуту населення. Ефективна економіка. $2019 . \quad$ № $2 . \quad$ URL: http://www.economy.nayka.com.ua/?op $=1 \& \mathrm{z}=6883$

9. Самусевич Я. В. Розвиток науково-методичних підходів до розуміння сутності податкової конкуренції. Вісник Української академії банківської справи. 2013. №2(35). С. 32-36.

\section{References}

1. Doing Business - 2017: Economy Rankings. World Bank Group. [Електронний pecypc]. URL: http://www.doingbusiness.org/

2. Global Foreign Direct Investments Country Attractiveness Index [Електронний pecypc]. URL: http://www.fdiattractiveness.com/ranking-history/

3. Human Development Reports [Електронний pecypc]. URL: http://hdr.undp.org/en/content/humandevelopment-index-hdi
4. Index Economic Freedom [Електронний ресурс]. URL: https://www.heritage.org/index/

5. PricewaterhouseCoopers [Електронний ресурс]. URL: https://www.doingbusiness.org/en/reports/thematicreports/paying-taxes-2019

6. The Global Competitiveness Report [Електронний pecypc]. URL: https://www.heritage.org/index/

7. Bezpalko, I. R. (2015), "Analysis of the competitiveness of the tax system of Ukraine in modern 
globalization", Efficient economy. URL: 2

http://www.economy.nayka.com.ua/pdf/10 2015/26.pdf

8. Neizvestna, O. V., Ovcharenko, O. V., Grebenyuk, I. V. (2019), "Tax competitiveness as an indicator of the level of welfare of the population", Efficient economy, vol.

2. http://www.economy.nayka.com.ua/?op $=1 \& z=6883$

9. Samusevich, J. V. (2013), "Development of scientific and methodological approaches to understanding the essence of tax competition", Bulletin of the Ukrainian Academy of Banking, vol. №2 (35), pp. 32-36.

\title{
Аннотация
}

Олексій Мазуренко, Інна Тютюник, Юлія Білоус

\section{СИСТЕМАТИЗАЦИЯ ФАКТОРОВ ФОРМИРОВАНИЯ НАЛОГОВОЙ КОНКУРЕНТОСПОСОБНОСТИ СТРАНЫ}

\begin{abstract}
Проанализировано экономическое содержание понятия «налоговая конкурентоспособность странь». С помощьюю инструментария Google Trends проанализирована динамика изменения количества поисковых запросов пользователей поисковой системы Google по вопросам формирования налоговой конкурентоспособности страны. По результатам трендового анализа сделан вывод о низком уровне заинтересованности пользователей в данных вопросах. Проведен анализ факторов формирования налоговой конкурентоспособности страны. Осуществлен сравнительный анализ уровня налоговой нагрузки отдельных стран мира в разрезе основных бюджетоформирующих налогов. Обоснована роль отдельных составляющих государственной налоговой политики (количество налоговых платежей, уровень налоговой нагрузки, эффективность деятельности государственных налоговых органов в направлении финансового мониторинга и контроля за полнотой начисления и уплать налоговых платежей, стабильность налогового законодательства) в снижение налоговой конкурентоспособности страны. Проанализирована динамика изменения позиционирования Украины в основных международных рейтингах. Выявлено, что существуюшие изменения 8 налоговом законодательстве не способствовали улучшению позиций Украинь по значению Индекса человеческого развития, Индекса Глобальной конкурентоспособности и Глобального индекса привлекательности иностранных прямых инвестиций. По результатам анализа сделан вывод о необходимости реформирования существующей системь налогообложения в Украине с точки зрения приведения ее в соответствие международным стандартам, оптимизации налогового законодательства и функционирования на приничиах устойчивости и согласованности.
\end{abstract}

Ключевые слова: налоговая конкурентоспособность, налоговая система, инвестиционная привлекательность, уровень налоговой нагрузки, ставка налога.

\section{Summary}

Oleksiy Mazurenko, Inna Tiutiunyk,, Yulia Bilous

\section{SYSTEMATIZATION OF FACTORS OF FORMATION OF THE TAX COMPETITIVENESS OF THE COUNTRY}

The article analyzes the economic content of the concept of "tax competitiveness of the country". Using the Google Trends toolkit, the dynamics of changes in the number of search queries of Google search engine users on the issues of forming the country's tax competitiveness was analyzed. According to the results of the trend analysis, a conclusion about the low level of user interest in these issues was made. The analysis of factors of formation of tax competitiveness of the country is carried out. A comparative analysis of the level of tax burden of individual countries in the context of the main budget-generating taxes. The role of certain components of the state tax policy (the number of tax payments, the level of tax burden, the effectiveness of state tax authorities in the direction of financial monitoring and control over the completeness of accrual and payment of tax payments, the stability of tax legislation) in reducing tax competitiveness is proved. The dynamics of changes in Ukraine's positioning in the main international rankings is analyzed. It was revealed that the existing changes in the tax legislation did not help to improve Ukraine's position on the value of the Human Development Index, the Global Competitiveness Index and the Global Foreign Direct Investments Country Attractiveness Index. Based on the results of the analysis, it is concluded that it is necessary to reform the existing taxation system in Ukraine in terms of bringing it in line with international standards, optimizing tax legislation and operating on the principles of stability and coherence.

Keywords: tax competitiveness, tax system, investment attractiveness, level of tax burden, tax rate. 